\title{
A BIBLIOMETRIC REVIEW ON DYNAMIC CAPABILITY
}

\author{
Yudi Yudistira ${ }^{*}$, , Yandra Arkeman ${ }^{* *}$, Trias Andati***), Siti Jahroh*) \\ ${ }^{*}$ School of Business, IPB University \\ Jl. Pajajaran Bogor 16151, Indonesia \\ ${ }^{* *}$ Department of Agroindustrial Technology, Faculty of Agricultural Engineering and Technology, IPB University \\ Fateta Building Floor 2, IPB Darmaga Campus, Bogor 16680, Indonesia \\ ${ }^{* * *}$ PPM School of Management \\ Jl. Menteng Raya No.9, Jakarta 10340, Indonesia
}

\begin{abstract}
Dynamic capability is an organization's ability to integrate, build, and rearrange its internal and external competencies to face the rapidly changing environment. The objectives of dynamic capabilities consist of (1) the capacity to sense and form opportunities and threats (sensing); (2) capacity to seize existing opportunities (seizing); and (3) the capacity to maintain competitiveness through upgrading, merging, protecting, and reconfiguring business assets, both tangible and intangible. This study aims to determine the development of dynamic capability research trends published by leading Scopus-based journals. The data analyzed consisted of 1194 indexed research publications from 2012 until 2021. The data is then processed and analyzed using the VoS viewer application to determine the bibliometric map of dynamic capability research development. There are several definitions of dynamic capability and implications for the firm environment.
\end{abstract}

Keywords: dynamic capability, bibliometric, Vos viewer, business environment, scientometric

Abstrak: Kemampuan dinamis adalah kemampuan organisasi untuk mengintegrasikan, membangun, dan menata ulang kompetensi internal dan eksternalnya untuk menghadapi lingkungan yang berubah dengan cepat. Sasaran kapabilitas dinamis terdiri dari (1) kemampuan merasakan dan membentuk peluang dan ancaman (sensing); (2) kemampuan menangkap peluang yang ada (seizing); dan (3) kemampuan untuk mempertahankan daya saing melalui peningkatan, penggabungan, perlindungan, dan konfigurasi ulang aset bisnis, baik berwujud maupun tidak berwujud. Penelitian ini bertujuan untuk mengetahui perkembangan tren penelitian kapabilitas dinamis yang diterbitkan oleh jurnal-jurnal terkemuka berbasis Scopus. Data yang dianalisis terdiri dari 1194 publikasi penelitian terindeks dalam masa penelitian sejak tahun 2012 hingga tahun 2021. Data tersebut kemudian diolah dan dianalisis menggunakan aplikasi VoS viewer untuk menentukan peta bibliometrik penelitian pengembangan kapabilitas dinamis. Ada beberapa definisi kapabilitas dinamis dan implikasinya terhadap lingkungan perusahaan.

Kata kunci: kapabilitas dinamis, bibliometrik, vos viewer, business environment, scientometric

\footnotetext{
${ }^{1}$ Corresponding author:

Email: yudistira.sbipb@gmail.com
} 


\section{INTRODUCTION}

From a strategic management point of view, there are two current approaches to explaining competitiveness. First, Porter (1979) is an approach that relies on an analysis of the company's external environment, where industry structure is a determining factor for the company's competitiveness. Second, Barney (1991) and Wenerfelt (1984) rely on the company's internal environment as a determinant of competitiveness, known as the resource-based view (RBV). RBV views that the crucial factors superior to competitors are resources, competencies, and capabilities. What is meant by company resources are physical and nonphysical resources that can be managed by the company to survive and perform high in business? Competence, technology, knowledge, skills, experience, capability are intangible assets known as "knowledge-based view" (Boisot, 1998).

The concept of dynamic capabilities was initially developed based on Resource-Based View (RBV). RBV is an influential theoretical framework in understanding how a company's competitive advantage is achieved and how that advantage can be maintained over time (Eisenhardt and Martin, 2000). In particular, the researchers mentioned that RBV assumes that a company can be conceptualized as a collection of resources. These resources are distributed heterogeneously (not the same) throughout the company, and these differences can persist over time. RBV has led researchers to theorize that when a company has very valuable, rare, inimitable, and non-replaceable resources, the company can achieve sustainable competitive advantage. The achievement is through implementing new value creation strategies that cannot be easily achieved easily imitated by other companies (Eisenhardt and Martin, 2000; Piening, 2013).

In line with the development of globalization, researchers have expanded the scope of the RBV to deal with a dynamic market share (Teece et al. 1997). Teece et al. (1997) mentioned that RBV has not adequately explained why and how a company could have a competitive advantage when facing a situation of rapid and unpredictable change. It is a situation where the competitive size has shifted, requiring companies to develop dynamic capabilities. Company managers integrate, build, and reconfigure their internal and external competencies to meet the changing organizational environment. In other literature, (Teece et al. 1997) also clarified again that for analysis, dynamic capabilities consist of (1) the capacity to sense and form opportunities and threats (sensing); (2) capacity to seize existing opportunities (seizing); and (3) the capacity to maintain competitiveness through enhancing, merging, protecting, and reconfiguring business assets, both tangible and intangible (managing threats/ transforming) (Teece, 2007, 2009).

Barreto (2010) mentions that the approach to the concept of dynamic capabilities expressed by Teece et al. (1997) builds on several main elements that highlight the main theoretical foundations: nature, role, context, creation, and development, benefit outcomes, and heterogeneity. Barreto (2010) explained the main elements that build dynamic capabilities in-depth. It consists of six elements, namely, the categorization of the nature of the dynamic capability concept. It is about how an organization's "ability" or "capacity" emphasizes the vital role of strategic organizational management. Second, the specific role that is built in this dynamic capability. The role is to integrate (coordinate), build, and reconfigure the organization's internal and external competencies. So that it assumes a change in perspective that mentions the role of organizational routines, path dependencies, and organizational learning. Third, dynamic capabilities focus on a particular external context, namely the rapidly changing organizational environment. Fourth, the assumption that dynamic capabilities are usually built rather than purchased from other parties, where the creation and evolution of organizations are embedded in organizational processes formed from the existence of company assets and evolutionary paths adopted in the past. Fifth, dynamic capabilities also emphasize the importance of organizational resources and capabilities as considered in the resource-based view (RBV). RBV is concerned with the importance of having diverse resources and capabilities across all parts of the organization because dynamic capabilities depend on unique asset positions on specific organizational paths. Moreover, the specific processes the organization undertakes. Finally, it is explicitly stated that the main result to be achieved by dynamic capabilities is a sustainable competitive advantage, for example achieving success over mistakes or providing a new value creation process. 
Zahra and George (2002) define dynamic capabilities as "change-oriented capabilities that help firms redeploy and reconfigure their resource base to meet evolving customer demand and competitor strategies." Zahra and George relate the company's dynamic capabilities with change management processes to meet evolving customer demands and to be able to face the strategies of competitors.

Another opinion from Zollo and Winter (2002) argues that dynamic capability is a patterned collective activity that can be learned so that the company systematically generates and modifies its work operations to make them more effective. This pattern indicates a continuous learning process in improving its performance. Dynamic capability does not mean a reactive action if it is felt that there is a change in the environment (Ferdinand et al. 2004).

Wang and Ahmed (2007) elaborated on the generic framework of dynamic capabilities consisting of three components: absorptive, adaptive, and innovative capabilities. Absorptive capability in applying organizational learning processes to recognize the value of new knowledge obtained from external sources, then assimilate it to be applied to the product or service produced (Wang and Ahmed, 2007; Cohen and Levinthal, 1990). Adaptive capability is the company's ability to identify new opportunities and then capitalize on these opportunities by configuring its internal resources to meet consumer needs (Wang and Ahmed, 2007). Innovative capability is the company's ability to produce innovations, both products or services marketed to consumers, in response to identified opportunities (Wang and Ahmed, 2007).

Eisenhardt and Martin (2000) distinguish dynamic capabilities based on two types of the external environment. First, the moderate dynamic external environment, where changes in the environment or market occur linearly, and the industry structure is relatively stable so that companies rely on the efficiency and exploit existing advantages. And second, the external environment is dynamically fast, which changes in the environment that is not linear, and the industrial structure continues to shift or change. In this condition, exploiting the advantages alone or data efficiency is not enough to be competitive. The dynamics of the company's capabilities are needed to see, adapt, and act as anticipation and response to the changes.
The number of research that explores dynamic capability makes it an issue that continues to emerge in the scientific literature in terms of quantity and greater breadth. This development is vital to investigate to find out how far the conversation concerning dynamic capacities has gone. In addition, this study is also vital to analyze the trend of this research and find out the famous things in this subject. Study results in the form of mapping may also be the basis for researchers on the dynamic capability subject to comprehend the overall picture of scientific research and develop it by other research objectives. Therefore, this first bibliometric study utilizing Scopus indexed journal article data may help exhibit the mapping of dynamic capability research and a guide for future research improvements.

\section{METHODS}

This study uses data from papers sourced from various journals from 2012-2021 with dynamic capability research. Data collection is done through searching for articles indexed Scopus database. The search is done by typing the keyword 'dynamic capability,' then selecting papers relevant to the dynamic capability research theme for journal criteria filtered and processed in software indexed by Scopus only journals equipped with DOI. From the search results, there are 1194 articles published from 2012-2021. This investigation was done in 2021, which necessitated selecting a research period from 2012 to 2021. In order to complete one business cycle, which lasts ten years, the most recent data for 2021 was pulled ten years earlier, in 2012. As a result, the Scopusindexed dynamic capabilities theme article's data is only available from 2012 through 2021. The data in topics used to publish dynamic capability-themed papers were analyzed using Microsoft Excel 2010. The trend of publication development on the dynamic capability theme was analyzed using VOSViewer software with the analytical method of Bibliometrics. Following are the number of articles from year to year (Table 1).

The computer program that was introduced was called VOSviewer. VOSviewer is a program developed for creating and viewing bibliometric maps. This program is available free of charge to the bibliometric research community (see www.vosviewer.com). VOSviewer can create author maps or journals based on co-citation data or create keyword maps based on shared incident data. The program offers a viewer that allows bibliometric maps to be examined in detail. 
Table 1. Publication period

\begin{tabular}{cc}
\hline Year & Number of Articles \\
\hline 2012 & 48 \\
2013 & 76 \\
2014 & 72 \\
2015 & 85 \\
2016 & 113 \\
2017 & 130 \\
2018 & 154 \\
2019 & 184 \\
2020 & 216 \\
2021 & 116 \\
\hline TOTAL & 1194 \\
\hline
\end{tabular}

It is a program that converts literary metadata into a bibliographic mapping with the properties of colored circles in network visualization, timeline details in overlay visualization, and density level in density visualization. VOSViewer is a popular tool in bibliometric research due to its ability to show a wide range of data types.

VOSviewer uses the VOS mapping technique to build the map, where VOS stands for visualization similarity. For previous studies where the VOS mapping technique was used. VOSviewer can display maps constructed using appropriate mapping techniques. Therefore, this program can display maps built using the VOS mapping technique and display maps built using multidimensional scaling techniques. VOSviewer runs on many hardware and operating system platforms and can be started directly from the internet.

\section{RESULTS}

\section{Bibliometric Graph Analysis}

Bibliometrics is based on the calculation and statistical analysis of scientific outputs in articles, publications, citations, patents, and other complex indicators. It is an essential tool in evaluating research, laboratory and scientist activities and scientific specialization, and country performance. After establishing the background for bibliometric development, the report presents the database from which the bibliometric was created and the primary indicators used.

This section will present a visual mapping chart from 1194 journals published by the dynamic capability to explore the meta-analysis results. The results of the keyword mapping analysis become the basis for mapping together important or unique terms contained in particular articles. Mapping is a process that enables one to recognize elements of knowledge and their configuration, dynamics, interdependencies, and interactions.

Related to bibliometrics, science mapping is a method of visualizing the field of science. This visualization is done by making a landscape map that can display topics from science (Royani et al. 2013). The results of network visualization from 1194 word map journals with the theme of dynamic capability can be seen:

\section{Co-Authorship Analysis}

Furthermore, the bibliometric results will be displayed based on the sub-themes, namely authors, organizations, and countries.

\section{Co-authorship Authors}

Using the VOSViewer software, we found the author's bibliometric mapping, as shown in the following Figure 1. The bigger the shape and the brighter the color, the author is publishing more and more writings related to dynamic capability. The appearance of cluster density depends on the level of yellow light brightness. It identifies that the yellow color on the map depends on the number of items associated with other items. This section helps get an idea ofthe general structure of a bibliometric map by paying attention to which parts of the light are considered essential to analyze. It is possible to interpret the authors who have published the most from the map.

In general, each researcher has different tendencies. Some writers are indexed as a single author, others coauthor with other researchers so that multiple clusters appear, indicating different densities. However, the authors with a reasonably large density indicate that they publish more research on dynamic capability than those with a lower density, so this result can be used to reference future researchers. Based on these results, the bigger and brighter the author's name, the more papers he published. The author's most published publications related to the theme of dynamic capability based on bibliometric mapping, namely Teece DJ. 


\section{Co-authorship Institution (Co-citation)}

In bibliometric analysis, the author's institution can be seen from which institution they come. We were able to interpret the institutions that wrote the most publications through these results. Based on the following Figure 2, the cluster of visible institutions with glowing circles shows how productive the institution is in contributing to publishing papers with dynamic capability. The most significant number of institutions is calculated from publications and links to other institutions, where an author can write many papers in different journals.

The most popular institutions are calculated based on the number of publications and links to other institutions, where a paper writer can write many papers in different journals. The ranking of the most famous institutions shown by the results of bibliometric mapping is Liverpool Business School, Liverpool John Moores University, Liverpool, United Kingdom.

\section{Co-authorship Country}

Furthermore, the visualization of the journal publisher mapping is illustrated in the bibliometric image of the journal source below. Based on the picture, it can be seen that several clusters of countries appear to publish the most articles with the theme of dynamic capability. Based on the Figure 3, the larger the circle of the publishing country, the more papers that country publishes. Seen that the United States has the brightest light. It means that the United States publishes the most dynamic capability-themed papers compared to other countries.

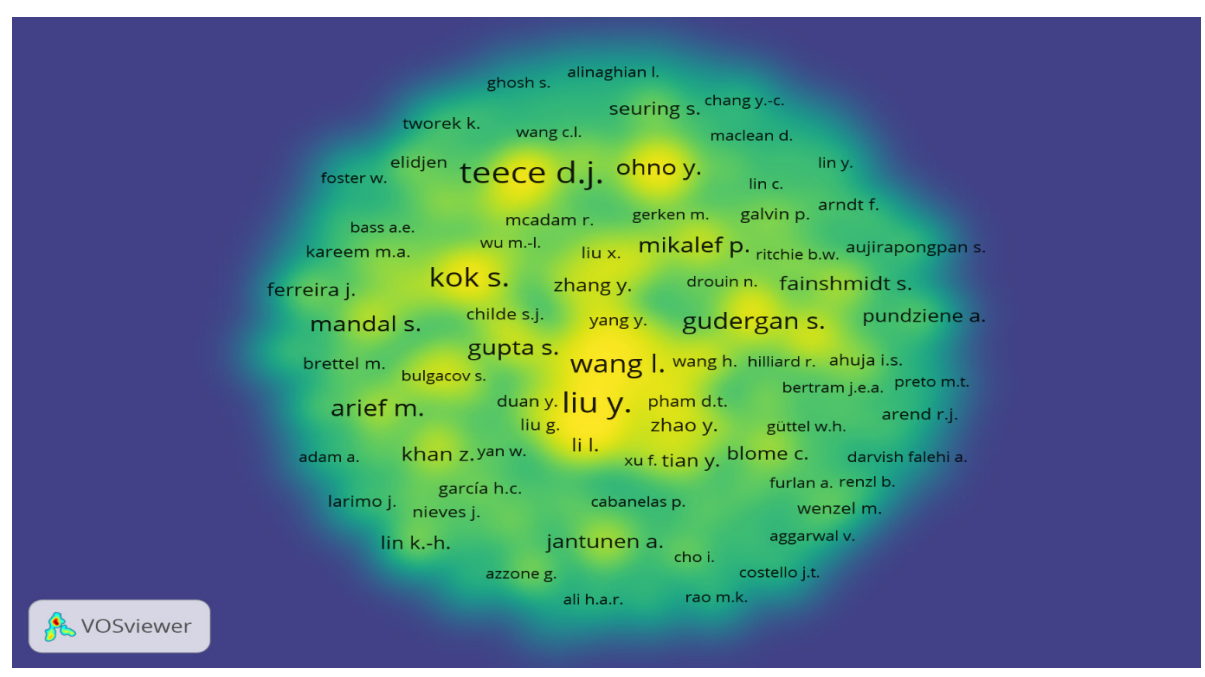

Figure 1. Co-authorship authors

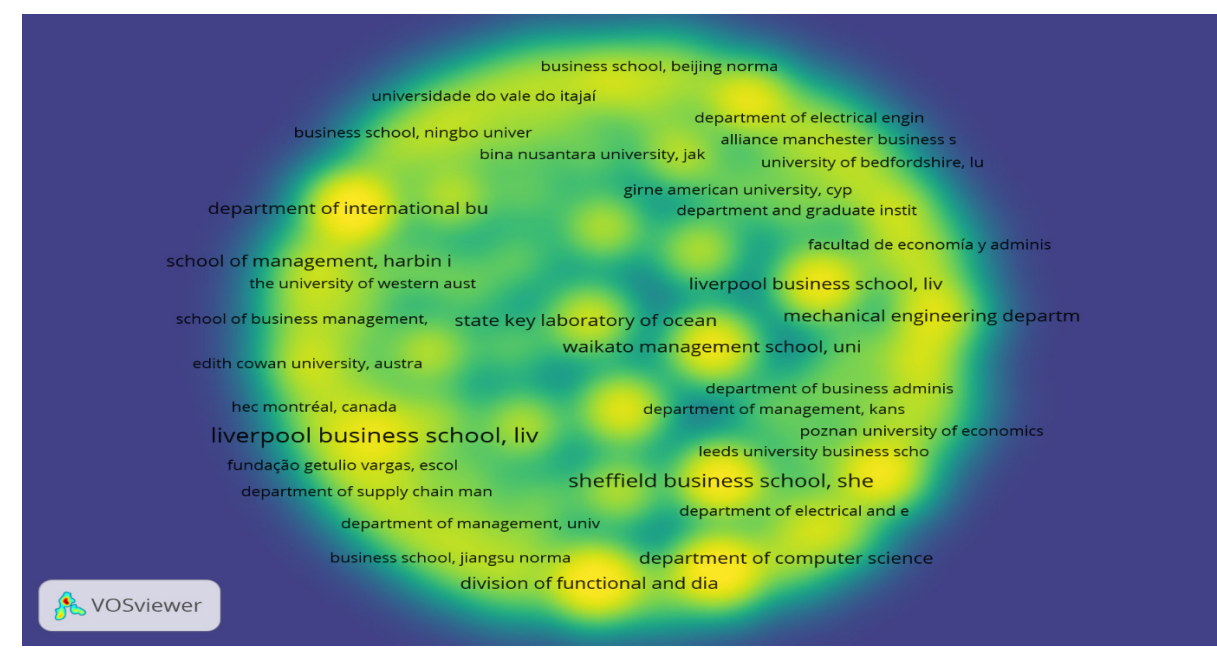

Figure 2. Co-authorship institution (Co-citation) 


\section{Co-occurrence Analysis}

Furthermore, the bibliometric results will be displayed based on the sub-themes, namely all keywords, author keywords, and index keywords.

\section{Co-occurrence All Key Word}

VOSViewer can also find a bibliometric mapping of the most used keywords in dynamic capability themes related to business strategy. The bibliometric mapping of the keywords used can be seen in the Figure 4 . Keywords with a more extensive form indicate that the word is used more in journals related to dynamic capability. This data can be used to find out the trend of keywords in recent times. The bibliometric analysis shows several widely used keywords in the paper that are the research object. The more keywords that appear, the wider the circle indication will be. While the line relationship between keywords shows how much they are related to other keywords. Based on the results of the analysis using VOSviewer on keywords themed dynamic capability, many clusters and interrelated with other keywords. Keywords that have the same color indicate a very close relationship. The most widely used keyword in dynamic capability-themed journals is dynamic capabilities.

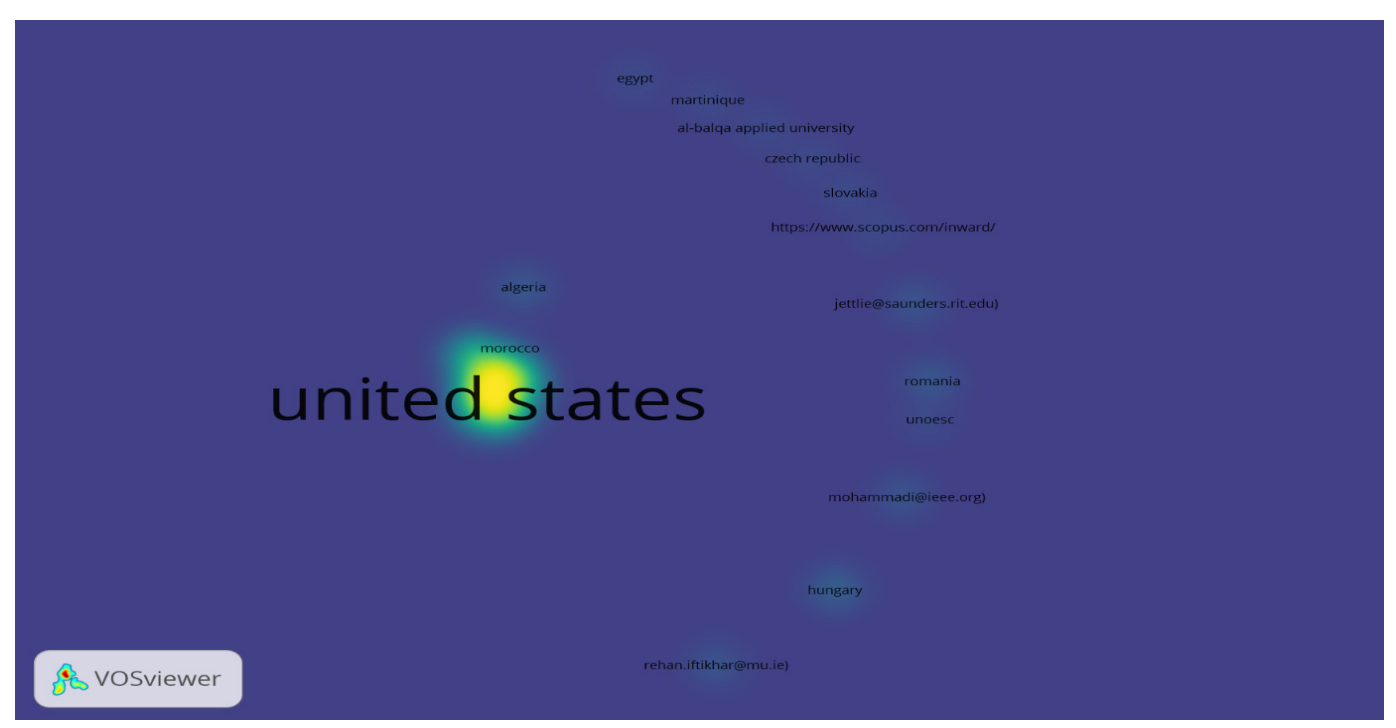

Figure 3. Co-authorship country

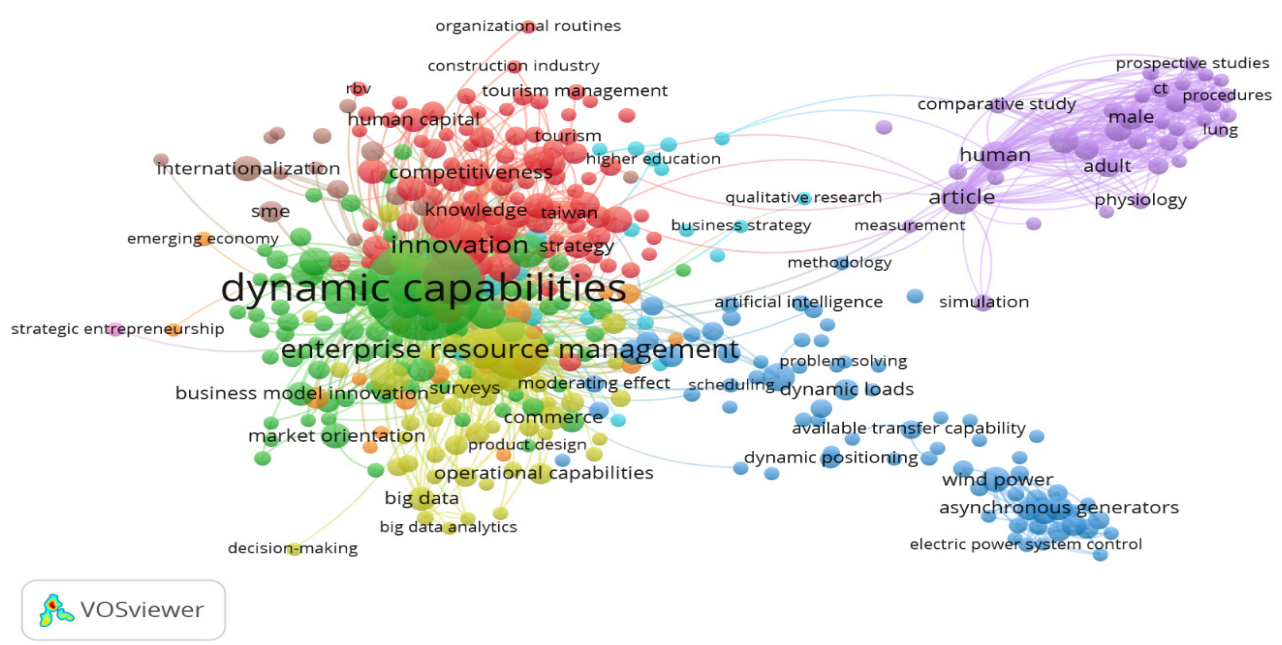

Figure 4. Co-occurrence all key word 


\section{Co-occurrence Authors Key Word}

VOSViewer can also find a bibliometric mapping of the most used keywords by authors in dynamic capability themes related to business strategy. The bibliometric mapping of the keywords used can be seen in the Figure 5. Keywords with a more extensive form indicate that the word is used more by authors in journals related to dynamic capability. Based on the analysis results using VOSviewer on keywords that authors widely use in journals with dynamic capability, there are many clusters interrelated with other keywords. Keywords that have the same color indicate a very close relationship. The most widely used keyword by the author is dynamic capabilities.

\section{Co-occurrence Index}

Then, this study also obtained results in the form of an index that is often used by the author and is related to the theme of dynamic capability related to business strategy, as shown in the Figure 6. An index that has the same color indicates a very close relationship. Based on the results obtained, the lighter the color, the more the index is used. In the word index of the paper with the theme of dynamic capability related to business strategy, several words are used the most, namely dynamic capabilities.

\section{Dynamic Capability Research}

Teece et al. (1997) argue that dynamic capabilities are essential for companies to remain competitive amid a dynamic changing environment. Dynamic capabilities enable companies to integrate, build and reconfigure their resources and competencies. Teece et al. (1997) explained that the company's competence must continue to be adapted to changes from outside the company. Process capability consists of (1) coordination and integration of observation activities;

(2) learning activities as collective social activities that can be in the form of experimenting with new things; (3) reconfiguration and restructuring of company resources based on observations of the market and the developing technological environment. Eisenhardt and Martin (2000) suggest that the dynamic capability process is "specific and identifiable routines," meaning work routines within the company that is specific, specific (idiosyncratic), and identifiable details.
Zollo and Winter (2002) view that the company's dynamic capability process is a series of evolutionary processes consisting of variation, selection, and implementation. Process variation means the company is looking for new ideas or knowledge to solve its problems or business challenges. Then through the selection process, potential ideas are evaluated to improve the efficiency of an existing business or work practices or even develop new, more efficient work practices. This selection process is closely related to the knowledge and experience that the company has previously, so it is logical that dynamic capabilities are called characteristics unique to each company. The third process, namely implementation, or routinization, is the implementation process, planting new ideas selected in the company's operations. In this selection process, it can be seen that dynamic capabilities cannot be separated from the strategic decision-making processes by the management.

Alsos et al. (2007) have developed a dynamic capability operational framework consisting of four dimensions, namely: (1) external exploration dimension; (2) internal exploration dimensions; (3) external exploitation dimension; (4) dimensions of internal exploitation. The manifestation of the external exploration dimension is observing the external environment to identify and evaluate external opportunities, adapting to technology and market developments, and adopting best practices. The internal exploration dimension is to acquire resources from outside through team member connections or networks with external parties. Related companies. The dimension of internal exploration is finding and implementing new initiatives obtained from new knowledge to allow the company to reconfigure its resources to support new ideas that will be implemented. The internal exploitation dimension is the renewal of company resources so that they can continue to be adaptive to various environmental changes and use new knowledge and experiences to produce innovations. Renewal of these resources can be done by increasing product development research and development, mobilizing or rotating employees to various appropriate projects to develop new knowledge and experiences. 


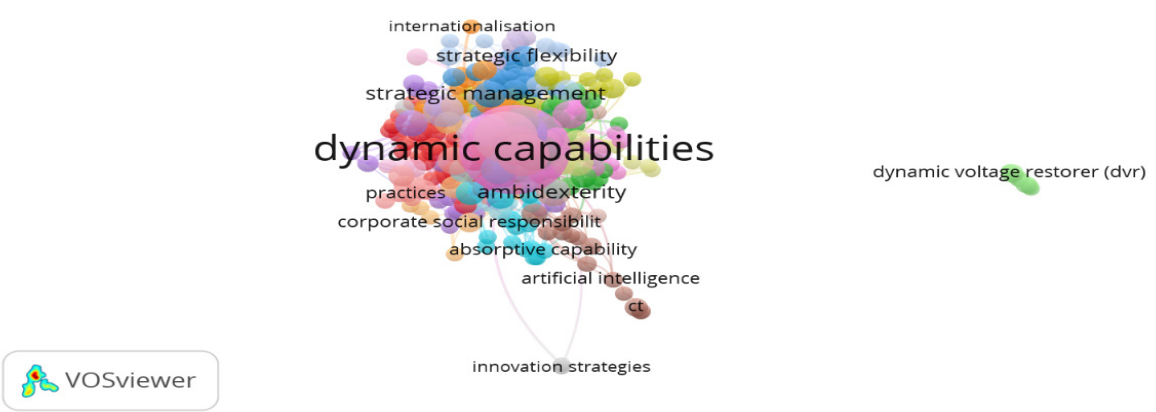

Figure 5. Co-occurrence authors key word

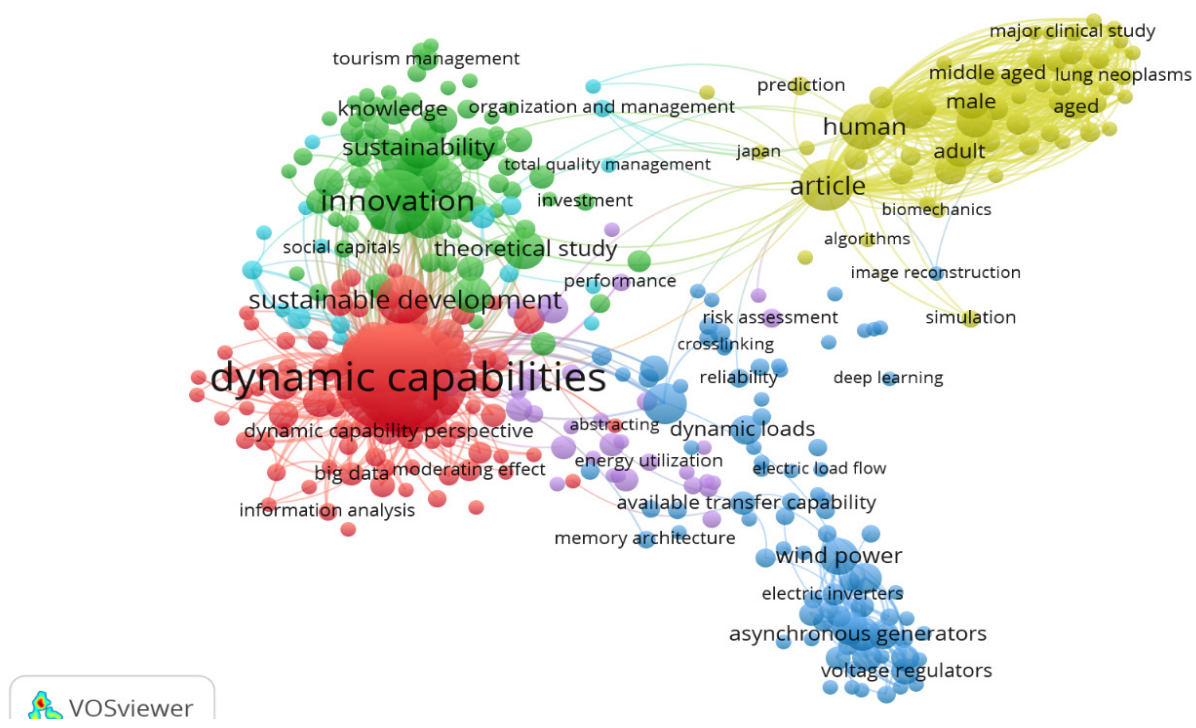

Figure 6. Co-occurrence index

The dynamic capabilities discussed above provide an overview of the company's ability to respond to external changes by continuously adapting and innovating. However, the company's life must simultaneously pay attention to the competitiveness and profits of the present and the survival of the future, short term and long term. How companies mix their resources in a balanced and optimal manner to produce competitiveness is a long and continuous learning process (March, 1991). The manifestation of its achievements can be seen from its innovations or are produced by the company. March (1991) elaborated the concept process of exploration and exploitation to explain how the company's learning process gathers resources to produce innovation. Exploitation exploits the advantages of existing physical and non-physical resources, an element of high certainty because doing business as it is already running increases efficiency. Profits can be predictable in the short term.

In contrast, exploration explores new possibilities through research, experimentation, flexibility in seeking and finding new alternatives. The element of certainty is low, and profit is likely to be obtained long-term. An example of exploration is developing new products aimed at emerging markets (Jansen et al. 2006).

March (1991) argues that companies are faced with problems how to balance the allocation of physical and non-physical resources in implementing exploitation and exploration strategies. Companies that focus on exploitation and close the possibility of exploration 
will face rigidities or so-called "core rigidities" (Barton, 1992). It locked on capabilities that can be utilized without making innovations. So to survive competitively in the long term, companies should exploit to strengthen their competitiveness at present and conduct explorations to ensure that they remain viable and competitive in the future.

Meanwhile, based on the results of bibliometric analysis, the following is a summary of the keywords, authors, and institutions most closely related to dynamic capability-themed research and studies.

\section{Managerial Implication}

Dynamic is a business reality today, namely a rapidly changing external environment (Teece et al. 1997; Erickson 2014) triggered by the speed of information circulation, a shorter learning curve for the discovery or innovation of new technologies and changes in socialeconomic factors. And unpredictable politics (Teece 2007; Winter 2003). To deal with external dynamics, an organization's ability to respond to external changes is necessary for a dynamic organizational capability. Dynamic capabilities are among the most promising frameworks on the strategic agenda to promote longterm survival factors (Barrales et al., 2014).

Teece et al. (1997) argue that dynamic capabilities are crucial for companies to remain competitive amid a dynamic changing environment. Dynamic capabilities that encourage the ability to integrate, build and manage the company's resources. This is an essential core of the importance of the dynamic capabilities of the organization or company.

Several studies have proven dynamic capability's positive and significant effect on firm performance. Wilden et al. (2013) explained that the impact of dynamic capabilities on company performance (sales growth and financial solvency) increased with a more organic organizational structure and greater competitive intensity. Chien and Tsai (2012) state that dynamic capabilities positively affect performance. Lin and $\mathrm{Wu}$ (2014) state that dynamic capabilities mediate the positive, valuable, rare, inimitable, non-substitutable (VRIN) and non-VRIN effects on firm performance. Ferreira et al. (2018) explain that dynamic capability affects managerial and marketing abilities and affects competitiveness and performance. Mu (2017) stated that dynamic capabilities contribute to the company performance by updating marketing and operations capabilities. Zhou et al. (2017) stated that dynamic capabilities with three dimensions, namely sensing capability, integrating power, and reconfiguring ability, facilitate innovation and improve company performance.

\section{CONCLUSIONS AND RECOMMENDATIONS}

\section{Conclusions}

This research aims to find out several journals written with the theme of dynamic capability. The results show that there has been an increase in the number of published articles on dynamic capability since 2012 . Research on dynamic capability has been widely carried out in various countries. An increase in the dynamic capability score will be positively related to economic growth, which makes economists do much research related to dynamic capability.

Research using the bibliometric method found that Teece DJ wrote the most about dynamic capability. The institutions that publish the most papers related to dynamic capability are Liverpool Business School, Liverpool John Moores University, Liverpool, United Kingdom. Moreover, the country that publishes the most papers related to dynamic capability is the United States. All keywords and the most widely used keywords by authors in journals with dynamic capability are dynamic capabilities for the index. At least eight definitions related to dynamic capabilities that academics and experts have suggested in this area.

This research is the first research that discusses dynamic bibliometric capability to be used as basic research for developing this theme in the future. This research also provides an overview of popular trends from research on this theme in further research.

\section{Recommendations}

For further research, bibliometric research can be developed using a text analytic biblioshiny program using article data from Scopus or web of science. The object of study can be expanded in other sectors such as the public sector, industry and other sectors 


\section{REFERENCES}

Alsos, Borch, Ljunggren, Madsen. 2007. Developing entrepreneurial orientation-the role of dynamic capabilities. Regional Frontiers of Entrepreneurship Research 94-105

Aoki M. 1990. The Participatory Generation of Information Rents and The Theory of The Firm. In M. Aoki, B. Gustafsson, and O.E. Williamson (Eds.), The Firm as a Nexus. London: Sage.

Arend RJ, Bromiley P. 2009. Assessing the dynamic capabilities view: Spare change, everyone?. Strategic Organization 7:75-90.https://doi. org/10.1177/1476127008100132

Barney JB. 1991. Firm resources and sustained competitive advantage. Journal of Management 17:99-120.https://doi. org/10.1177/014920639101700108.

Barreto I. 2010. Dynamic capabilities: A review of past research and an agenda for the future. Journal of Management 36(1):256-280.https://doi. org/10.1177/0149206309350776

Barton LD. 1992. Core capabilities and core rigidities: a paradox in managing new product development. Strategic Management Journal 13:111-125. https://doi.org/10.1002/smj.4250131009.

Boisot M. 1998. Knowledge assets: Securing competitive advantage in the information economy in october.

Cohen WM, Levinthal DA. 1990. Absorptive capacity: A new perspective on learning and innovation. Administrative Science Quarterly 35(1):128152. https://doi.org/10.2307/2393553

Eisenhardt KM, Martin JA. 2000. Dynamic capabilities: what are they?. Strategic Management Journal 21(10-11):1105-1121.

Ferdinand, Graca, Antonacopoulou, Easterby-Smith. 2004. Absorptive capacity: A process perspective in management learning.

Helfat CE, Finkelstein S, Mitchell M, Peteraf MA, Singh H, Teece DJ, Winter SG. 2007. Dynamic Capabilities: Understanding Strategic Change in Organizations. New Jersey: Blackwell Publishing.

Helfat CE, Winter SG. 2011. Untangling dynamic and operational capabilities: Strategy for the neverchanging world. Strategic Management Journal 32:1243-1250.https://doi.org/10.1002/smj.955

March JG 1991. Exploration and exploitation in organizational learning. Organization Science 2:71-87.https://doi.org/10.1287/orsc.2.1.71
Neo BS, Chen G. 2007. Dynamic Governance: Embedding Culture, Capabilities And Change In Singapore (English Version). Singapore: World Scientific.

Pablo AL, Reay T, Dewald JR, Casebeer AL. 2007. Identifying, enabling and managing dynamic capabilities in the public sector. Journal of Management Studies 44(5):687-708. https://doi. org/10.1111/j.1467-6486.2006.00675.x

Piening EP. 2013. Dynamic capabilities in public organizations. Public Management Review 15(2):209-245

Porter ME. 1979. How competitive forces shape strategy. Harvard Business Review 57(2):137145.

Royani Y, Bachtar MA, Tambunan K, Tupan, Sugiharto. 2013. Pemetaan karya tulis ilmiah LPNK: Studi kasus LIPI dan BPPT (2004-2008). BACA: Jurnal Dokumentasi dan Informasi 34(1):1-28.

Schweizer L, Rogber S, Michaels B. 2015. The dynamic capabilities persfective: from fragments to meta theory. Management Research review 38(7):662-684.

Teece DJ. 2007. Explicating dynamic capabilities: the nature and microfoundations of (sustainable) enterprise performance. Strategic Management Journal 28(13):1319-1350.

Teece DJ. 2009. Dynamic Capabilities and Strategic Management. New York: Oxford University Press Inc.

Teece DJ, Pisano G, Shuen A. 1997. Dynamic capabilities and strategic management. Strategic Management Journal 18(7):509-533.https://doi. org/10.1142/9789812834478_0002

Teece DJ, Pisano G, Shuen A. 1990. Firm capabilities, resources and the concept of strategy [economic analysis and policy working paper]. California: University of California.

Wang, Ahmed. 2007. Dynamic capabilities: A review and research agenda in international. Journal of Management Reviews 9(1): 31-51. https://doi. org/10.1111/j.1468-2370.2007.00201.x

Zahra SA, George G. 2002. Absorptive capacity: A review, reconceptualization, and extension. The Academy of Management Review 27(2):185203.https://doi.org/10.2307/4134351

Zollo M, Winter SG. 2002. Deliberate learning and the evolution of dynamic capabilities. Organization Science 13(3):339-351. https://doi.org/10.1287/ orsc.13.3.339.2780 